\title{
Har Grundtvig-Selskabet forsømt Digteren Grundtvig?
}

af Gustav Albeck

I hvor høj grad beskæftigede forskningen sig i tiden op mod 1940 med digteren Grundtvig, og hvordan var den faglige kritik af hans digtning $\mathrm{i}$ begyndelsen af dette århundrede?

Jeg finder det hensigtsmæssigt at indlede med et forsøg på at besvare disse spørgsmål, inden jeg prøver på at formulere et svar på det problem, jeg rejser i overskriften. Emnet er ikke valgt som følge af indignation endsige harme over eventuelle undladelsessynder fra Grundtvig-Selskabets side, men ud fra overbevisningen om, at en mere omfattende forskning af digteren Grundtvig synes at have et voksende krav på den yngre forskergenerations skærpede opmærksomhed.

I en afhandling betitlet Grundtvigianisme I (i bogen "Gejstlige og verdslige Breve«, 1937) tegnede Paul V. Rubow et på een gang positivt og maliciøst billede af Grundtvig-forskningens status kort før frembruddet af det, som man kunne kalde "nyere Grundtvig-forskning". Det hedder bl.a.: "Grundtvig er - tilligemed Holberg og H. C. Andersen - den store Reserve, vi danske Litteraturforskere kan ty hen til, naar vore svenske Kolleger i berettiget Stolthed henpeger på det Bjerg af Monografier, hvorunder enhver af deres store eller halvstore eller helt smaa Forfattere er videnskabeligt eller halvvidenskabeligt begravet. De har saa ikke andet at sige, naar man viser dem det vidtløftige Bogskab med Skrifter og Afhandlinger om Grundtvig, end at det meste ikke er skrevet af Litteraturforskere, men af Tilhængere. - Saa meget desbedre, maa vi da svare. Thi hvad er selv den pertentligste, udvidet. 
synspunktbestemte Skelettering i Sammenligning med en Fremstilling, som er øst af levende Væld? I Forskerens kunstfærdige Net lader sig blot indfange, hvad der er forudset; hos Tilhængere finder man meget af det, som ikke lod sig beregne. De Lærdes Afhandlinger er som Prospekter, der bare taaler at ses fra eet Udsigtspunkt. Grundtvigianernes er som Billeder, der kan flyttes og tages ned og hænges op, men som altid bliver sig selv lig, om de end ikke altid ligner Modellen slaaende. "

Den hele svada synes skrevet af en kritiker iført fløjlshandske, men overalt fornemmes den skarpe klo, der truer med at trænge gennem handsken. Bag den dæmpet-sarkastiske konstatering af en kvantitativ stor subjektivt præget indsats lurer fagmandens efterlysning af en forskning, der på videnskabelig grund kunne bringe ny viden frem om N.F.S. Grundtvig og da navnlig om digteren.

Af Rubow-citatet kunne man let bringes til den opfattelse, at Grundtvigianernes talrige skrifter og afhandlinger om Grundtvig blot var udslag af tilhængernes trang til at hylde mindet om den store afdøde eller betroelser vedrørende deres subjektive forhold til digteren og kirkemanden. En sådan dom er ikke retfærdig. I det bjerglandskab af skrifter om Grundtvig, der - for at blive i Rubows billede - udgør "tilhængernes " voluminøse produktion, rager i hvert fald 3 spidser op, 3 skribenter, der i kraft af, men også på trods af, deres tilhørsforhold til den grundtvigske bevægelse, har ydet en værdifuld forskningsindsats vedrørende åndskæmpen. Det er Fredrik Nielsen, Frederik Rønning og Holger Begtrup.

Af disse havde Fredrik Nielsen (1846-1907) en svagere tilknytning til Grundtvigianismen end de to andre og skiller sig ud fra mængden af skribenter fra Grundtvigforskningens første periode ved at være professionel forsker, universitetslærer, professor $\mathrm{i}$ kirkehistorie ved Københavns Universitet - siden biskop (i Aalborg og Århus). Som teologisk professor forsvarede han Grundtvigs teologi over for kollegers angreb, og i 1889 udsendte han i anledning af 50-året for Grundtvigs ansættelse som præst $\mathrm{i}$ Vartov et såkaldt "Mindeskrift" med titlen N.F. S. Grundtvigs religiøse Udvikling. Den 340 sider store bog, der i henseende til centrale problemer havde en forgænger i digteren og kritikeren Rudolf Schmidts vægtige afhandling: Grundtvig og den tyske Orto- 
doxi (kommet som bog i 1885) er en på lange citater og flittig brug af utrykt materiale bygget skildring af Grundtvigs liv og udvikling fra fødselen til året 1839 - og således et nyttigt og videnskabeligt velfunderet supplement til nordmanden $\mathrm{H}$. Bruns vidtløftige og noget diffuse monografi: "Biskop N. F. S. Grundtvigs Levnetsløb» (1882ff).

Ligesom Fredrik Nielsen hørte Frederik Rønning (1851-1929), der var litteraturhistoriker af fag, til de privilegerede, der tidligt fik adgang til Grundtvig-arkivet, og drog nytte deraf. Det spores ikke så meget $\mathrm{i}$ hans lidet givende skrift om Grundtvig som astetiker (1883) og andre afhandlinger fra Rønnings ungdom, men blev til gavn for hans store monografi N.F. S. Grundtvig, et bidrag til skildring af dansk åndsliv $i$ det 19. århundrede I-IV, 1907-1914. Den blev til midten af vort århundrede den største samlede skildring af Grundtvigs liv og bidrog ved sin fremkomst til øget og veldokumenteret viden om sit emne. Fremstillingen er til tider forceret livfuld. Altfor ofte udsætter forfatteren sin engagerede læser for det ubehag, der er en følge af en nidkær apologets ihærdighed.

Som litteraturhistoriker af fag kunne Rønning ingenlunde se bort fra, at Grundtvig var en stor digter, men han evnede ikke at åbne op for et indblik i det særprægede og værdifulde i Grundtvigs digtning. Han var mere parafrasens end analysens mand.

Den tredje markante Grundtvigforsker fra tiden før 1940 var højskolemanden Holger Begtrup (1859-1937). Også han var akademiker, cand.theol. allerede som 21 -årig. Han viede sit liv til højskolen og størstedelen af hans forfattergerning var udforskning og fremstilling af Grundtvigs liv og virke. Han karakteriseredes med rette som sin samtids "lærdeste Kender af Grundtvig “. Hans mest fortjenstfulde indsats blev tibindsudgaven af Grundtvigs udvalgte Skrifter (1904-1909), som i nogen udstrækning bragte hidtil utrykte dele af Grundtvigs forfatterskab på tryk, og som på det nærmeste er et mønster på omhu og akribi, men som kun nødtørftigt lader digteren få ordet.

Fire små ungdomsskrifter fra Begtrups hånd hævdede længe en anerkendt særstilling inden for Grundtvigforskningen ved deres nøgterne og solide opbygning: Grundtvigs kristelige Opvakkelse $i$ Vinteren 1810-11 (1899), Grundtvig som Bibelkristen (1900), Grundtvigs kirkelige Syn 1825 (1901) og Grundtvigs Kamp for kirkelig Frihed (1905). På sine gamle dage afrundede Begtrup disse smukke 
bidrag til Grundtvigforskningen med tobindsværket N.F.S. Grundtvigs danske Kristendom (1937), der som ungdomsbøgerne bygger solidt på forfatterens fortrolighed med Grundtvigs vældige produktion, den trykte som den utrykte. Fra hans alderdom hidrører en populær Grundtvigmonografi - oprindelig udkommet på islandsk under titlen Grundtvigs Saga. Både denne og bogen om Grundtvigs danske Kristendom var motiveret med ønsket om at holde mindet om Grundtvigs virke levende i det danske folk, eller måske snarere frygten for at mindet om ham og hans gerning var i dalen.

Det var troens kæmpe, højskolens inspirator og den folkelige vækker, som var hovedmålet for Begtrups omfattende forfatterskab. Ikke desto mindre var et af hans første bidrag til litteraturen viet digteren Grundtvig, nemlig hans omhyggelige udgave (med kommentarer) af Nyaarsmorgen (1901). Digtet havde indtil da været så godt som upåagtet af litteraturhistorikerne. Det nævnes exempelvis ikke i P. Hansens i sin tid så udbredte Illustreret dansk Litteraturhistorie (1896) - ja end ikke i den "forøgede " udgave fra 1902, men digtet har på grundlag af Begtrups edition inspireret til omfattende studier og analyser i vore dage.

Udover Begtrup har andre betydelige højskolefolk skrevet om Grundtvig: Hans Rosendal, hvis populære bog (1901) fandt vid udbredelse, og Thomas Bredsdorff, der i 1917 gav en stærkt personlig skildring af skjalden og profeten. På denne linie møder man også Johan Borup, der midt under 2. verdenskrig udsendte en stærkt forøget udgave af sin bog "Grundtvigs Stjerne" (fra 1912), udformet til en smuk og dybt personlig folkelig biografi "N. F. S. Grundtvig" (1943).

Når Rubow i det ovenanførte citat indlemmede Grundtvig blandt de digtere, som "vi danske Litteraturforskere" kan henvise til, når det gælder at kappes med de ihærdige svenske kolleger, er det ikke blot en maliciøs vurdering af ensidige tendenser hos kolleger i broderlandet, men en bevidst kritik af afdøde danske kollegers undladelsessynder. Han vidste bedre end nogen, at det autoriserede lav af litteraturforskere under og efter "det moderne Gennembrud" holdt sig på afstand af den kristne skjald og hans venneskare.

Grundtvig havde ikke selv været uden skyld i, at der havde rejst sig en ismur mellem ham og universitetet. Under proviso- 
rierne og positivismens højkonjunktur noteredes Grundtvigs aktier ikke højt på den litterære københavnske børs. Eller snarere: de noteredes slet ikke. Hvad Georg Brandes, der ellers har skrevet så meget og ofte så smukt om vore store Guldalderpoeter, fik skrevet om Grundtvig, kan være i en lommebog. For den berømte moderne kritiker var Grundtvig en pest, skønt han erkendte, at han var en af åndslivets giganter. Hans sekretær, fru Gertrud Rung, beretter i sine erindringer følgende lille episode (fra 1915):

"Jeg kom en Dag med en respektløs Udtalelse om Grundtvig. G. B. slog Hænderne sammen i Forfærdelse: "Men Barn dog! hvor kan De sige sligt Nonsens. Grundtvig var en stor Mand. Jeg for min Part afskyer ham, men han var Fanden ta' mig en stor Mand " ", (anf.skr.pag. 43). Et par år senere synes Brandes at have været inde på tanken om at skrive en artikel om Grundtvig og Baggesen - formentlig i anledning af hundredåret for "Tylvtestriden ". Men han slængte bogstavelig talt opgaven fra sig: "gav Biblioteket Grundtvig, Baggesen og alt det Pøjt tilbage, vil intet skrive derom ", hedder det i fru Rungs skrift (pag. 79).

Det var ikke nogen tilfældighed, at det var Edvard og ikke Georg Brandes, der i 1883 skrev mindeartiklen i hundredåret for Grundtvigs fødsel i venstrepartiernes hovedstadsorgan "Morgenbladet «. - En artikel, som ikke levnede digteren Grundtvig megen ære, og som forøvrigt bidrog til det opgør inden for Venstre, der førte til udgivelsen af dagbladet "Politiken " - og "Morgenbladet «s langsomme henvisnen. Afstanden mellem det grundtvigske Venstre og europæerne, i hvis kreds det litterære Venstre søgte tilhold, blev til en afgrund. Det var ikke velset blandt litteraturens folk at interessere sig for digteren Grundtvig. Endnu så sent som o. 1906 kunne en begavet ung adjunkt ved en af de jyske statsskoler uden at udsætte sig for faglig kritik affærdige skjalden med følgende svada til en klasse: "Nu kommer vi til Grundtvig. Han var tre gange gift og tre gange sindssyg - og det kan jo komme ud på eet. Vi går over til at tale om Carsten Hauch" .

Der skulle faktisk gå adskillige årtier efter Grundtvigs død, før det blev god tone blandt litterære akademikere at beskæftige sig positivt og loyalt med Grundtvigs digteriske forfatterskab. Selvfølgelig var der undtagelser som f.eks. Georg Brandes' samtidige - og potentielle rival - H. S. Vodskov. Han skrev i 1880 en bemær- 
kelsesværdig god og positiv anmeldelse af første bind af Poetiske Skrifter, hvori han som den første fremhæver "saa mærkelige Arbejder som Nyaarsmorgen og Roskilde-Rim, sande levende, lyriske Floder, hvis Friskhed og strømmende Fald man ikke kan blive træt af at beundre". Vodskov går ikke af vejen for at betegne Grundtvig som Digter og det "en af vore største". Der ligger i Vodskovs korte, men fortættede analyse af bogen spiren til en rigere og mere nuanceret karakteristik af lyrikeren N. F. S. Grundtvig end i Valdemar Vedels kyndige, men lidt kolde og kantede skildring af skjalden i Studier $i$ Guldalderen $i$ dansk Digtning (1890, p. 136-146). Vedel savnede hverken kompetence eller vilje til objektivitet, men var uden indforståethed med en ånd som Grundtvigs, opvokset som han var i et kulturmiljø præget af de heibergske dannelsesidealer og af Heiberg-eleven Brandes' litterære modernisme. Langt bedre betingelser for at indleve sig i Grundtvigs tanke og litterære virke havde Vedels samtidige, provstesønnen Vilh. Andersen, der i Illustreret dansk Litteraturhistorie III (1924) lod billedet af digteren Grundtvig træde stærkt frem. Forinden havde hans senere universitetskollega Hans Brix så tidligt som i 1912 henledt opmærksomheden på salmedigteren Grundtvig i nogle smukke analyser i bogen "Tonen fra Himlen«. Men han nåede aldrig at forlige sig med Grundtvigs øvrige fortjenester. "Det gamle Vrøvlehovede“ kaldte han ham så sent som i 1955 (i et brev til undertegnede).

Takket være "Tonen fra Himlen" kom Brix - kort før første Verdenskrigs udbrud - til at figurere som en betydelig faktor $\mathrm{i}$ den "Grundtvig-Revision", som digteren L. C. Nielsen i 1913 indvarslede $i$ en kronik $i$ brødrene Brandes' indflydelsesrige hoforgan: Politiken. Dens indhold har formentlig confunderet ikke blot Brix, men største delen af det radikale blads abonnenter, for så vidt som L. C. Nielsen - i voldsomme vendinger - gjorde front til to sider: Gammel-grundtvigianismen, som "tilbad et Billede af ham (Grundtvig), der kun var en dilettantisk Gengivelse af hans virkelige Træk " - og den øvrige del af folket, der "stod ligegyldigt over for ham eller helt uvidende om hans Betydning". Kronikøren mente, at "en ny og menneskeligere Opfattelse af Grundtvig (var) ved at danne sig«. En fornyelse var »blevet paabegyndt i Litteraturen. Før gik den moderne Kritik uden om ham". Den ændrede holdning kunne bl.a. aflæses af "Hans 
Brix’s Forsøg paa at genindsætte ham i hans retmæssige Plads som Digter".

Det var næppe tilfældigt, at Vilhelm Andersens navn ikke blev nævnt i L. C. Nielsens artikel. Han holdt sig oftest på afstand af aktuelle debatter og var i årene før første Verdenskrig optaget, dels af den universitetsgerning, han i 1908 var kommet ind i ved sin udnævnelse til professor, dels af videreførelsen af sit planlagte mammutværk "Tider og Typer af dansk Aands Historie", i hvis første bind (1907) han havde gjort rede for sit ambitiøse projekt og skitseret sine planer for de følgende bind.

Det stort anlagte projekt blev aldrig fuldført. "Tider og Typer " blev en torso kun omfattende første "række": "Skolen" med værkerne om Erasmus, Goethe og Horats. Men meget af den viden og de synspunkter, han havde tiltænkt fortsættelsen af "Tider og Typer", kom ham til nytte, da han som universitetslærer forelæste over perioden 1800-1850 - og udformede indholdet af tredje bind i "Illustreret dansk Litteraturhistorie", som udkom i 1924. Det spores ikke mindst i hans skildring af Grundtvig.

Kun 24 år gammel havde han - på opfordring af redaktøren af et litterært tidsskrift i St. Petersborg - skrevet en kort oversigt over hele den danske litteraturhistorie. Artiklen er i sin danske form offentliggjort i et skrift, som Det danske Sprog- og Litteraturselskab udgav i 1985 med titlen, "Om at skrive den danske ånds historie", (med kommentarer af Per Dahl). Vilhelm Andersen roser heri Grundtvig for at være trængt dybere ind i Nordens oldtid end Oehlenschlæger. Hverken mere eller mindre om digteren! Men det fremhæves, at han var talsmand for "en ejendommelig kristelig-folkelig opfattelse" - og det noteres i en parentes, at Grundtvig og Mynster, hver på sin vis havde "genfødt det kirkelige liv i Danmark ". I det bevarede manuscript har Vilhelm Andersen anbragt bogstaverne S.K. over dette udsagn - og må senere have tilføjet, at Kierkegaard var "et af de mest begavede Mennesker i Danmark ". I denne forbindelse nævnes også hans angreb på "den officielle Kristendom ".

Det er næppe tilfældigt, at Vilh. Andersen, da han i $1888 \mathrm{skrev}$ sin lille "russiske" oversigt, synes at have været ved at "glemme", at Grundtvig i Kierkegaard havde en langt farligere medkæmper og modstander end J. P. Mynster. Det er nok for dristigt heraf at slutte, at den unge Vilh. Andersen var mere engageret $i$ 
det grundtvigske kristendomssyn end i det kierkegaardske, og at han måske tillagde Grundtvigs gerning som præst og folkelig opdrager og forkynder langt større betydning for udviklingen af dansk ånd end Kierkegaard med dennes ubønhørlige krav om "det personlige forhold til det guddommelige". Men så sent som i et brev af 10. marts 1904 taler Vilh. Andersen om sine planer til 2. række af "Tider og Typer«: "Kristusbøgerne, hvoraf jeg nu skimter Luther og Grundtvig ". Og altså ikke Kierkegaard!

Først i 1907, i forordet til bind I af "Tider og Typer af dansk Aands Historie" (som torsoen kom til at hedde), siges det om det planlagte afsnit "Kristusbøgerne" (som nu havde făet navnet Kirken): "Ogsaa denne Undersøgelse vil falde i tre Dele, hvoraf den første handler om Lutherdommens klassiske Tid og dens Eftervirkninger, de senere om de to starke Rorelser $i$ det religiøse Liv $i$ og uden for Kirken, der kan knyttes til Grundtvigs og Kierkegaards Navne" (udhævet af G. A.). - Af denne jævn- og modstilling voksede et syn frem, der kom til at præge store dele af Vilh. Andersens skildring af sidste halvdel af seklets åndshistorie. Men det kommer først klart tilsyne i hans afsnit om Kierkegaard i Litteraturhistorien (specielt i bd. III, pag. 700). Kapitlet om Grundtvig har derimod karakter af en mandjævning med Oehlenschlæger. Det har samme omfang som kapitlet om "Skjaldenes Adam", og er præget af litteraturhistorikerens trang til at modstille to store digtere.

Oehlenschlæger bærer hos Vilh. Andersen prisen. Grundtvig er den digtende profet og salmisten - til nød skjalden. Til gengæld nærer Vilh. Andersen både respekt og beundring for åndspersonen: kristendommens forkynder, troens kæmpe, historikeren, mytologen og folkeoplyseren og i mindre grad filologen. Hans fremstilling af Grundtvigs folkelige og kristelige liv og virke er imponerende indsigtsfuld og detaljerig - og optager over halvdelen af det store Grundtvig-kapitel. Den peger på en række af de problemer, som den nyere Grundtvig-forskning har taget op til behandling.

Da Vilh. Andersen i sidste halvdel af sit Grundtvig-afsnit kommer til Grundtvigs poetiske værker, er det mærkbart, at han ikke blot erkender, men også gribes af den rige og storladne poetiske kraft, Grundtvigs digtning rummer, først og fremmest vælden i det længe oversete kvad "Nyaarsmorgen". Han roser 
Begtrups flid og omhu ved udgivelsen og kommenteringen af det, og søger selv at trænge dybere ind i dets visionære poesi. Trods sin grebethed finder han det "urimeligt at hæve dette Digt ... til Vølvespaas og Guldhornenes Højder «, da dets poetiske fylde og flugt tynges af det litterært poetiske stof, "i hvis Stil store Syner omveksler med platte Ordspil«. Afstanden til Oehlenschlæger fremhæves således også her.

Det tilkom en senere generation med navne som Poul la Cour (Fragmenter af en Dagbog), Aage Henriksen, Poul Behrendt, Jørgen Elbek og Poul Borum at yde Nyaarsmorgens digter en større retfærdighed. Vilh. Andersen henviser den læser, "der ikke evner at overskue det store Digt med Ørneflugt" til det mindre digt fra samme tid: "De levendes Land " - et digt, som en hel flok af vor tids litteraturforskere har lagt mange kræfter og evner $i$ at tolke. "Dersom man af alt, hvad Grundtvig har skrevet, skulde udvælge et Blad til at give dem, som kun kender lidet til Grundtvig selv et levende Indtryk, ligesom et Haandtryk af ham, helt som han er - Digteren og Præsten - maatte det blive dette religiøse Digt «, skriver Vilh. Andersen.

Helt giver han sig hen i uforbeholden beundring for digteren Grundtvig i sin omtale af oversættelsen af det angelsaksiske digt, som man har tillagt Kædmon: "I Kvæld blev der banket på Helvedes Port". "Sangværkets bedste Digt" skriver han, og tilføjer, "hver Strofe er et Syn, men her er tillige hvert Syn et Billede. $\mathrm{Og}$ i disse Billeder er der en sjælden Forening af de to Elementer i Grundtvigs Poesi: det starke og det milde, der fuldbyrdes paa det Sted, hvor Menneskenes Søn kysser Menneskenes Moder «:

Fra Sol-Øine milde to Taarer nu faldt

- og underfuldt var det at skue

med dejlige Farver i Kronegestalt

sig danned om Eva en Bue.

- Saa kyssed sin Moder Guds Herligheds Glans

til Under for alle de Døde -

og op stod som Dronning med Regnbuekrans

skøn Eva, som angred sin Brøde.

Her synes Vilh. Andersen parat til at jæunstille de to digtere, Oeh- 
lenschlæger med den plastiske billedstil - overfor visionernes skjald.

I indledningen til sit Grundtvig-kapitel markerede han iøvrigt forskellen mellem Oehlenschlæger og Grundtvig ved at hævde, at Grundtvig - i modsætning til Oehlenschlæger - ingen klassiske værker har skrevet - et postulat, der formentlig var inspireret af den tavshed om digteren Grundtvig, der herskede i tiden omkring århundredeskiftet. Da Vilh. Andersen i sit kapitel om Grundtvig nåede frem til at skildre digteren, kom han til at modbevise dette postulat. Han har, omend lidt modvilligt, været med til at gøre "Nyaarsmorgen" til et klassisk værk - ligeledes "Paaskeliljen", som han var med til at bringe til opførelse på Det Kgl. Teater på en række påskeaftner - (som et led i indsamlingen til bygningen af Grundtvig-Kirken) - ligesom hans omtale af Grundtvigs salmedigtning dementerer hans påstand om, at Grundtvig intet klassisk værk har skrevet. En betydelig part af den danske salmebog er en del af Grundtvigs poetiske arv - ikke blot til menigheden, men til poesiens venner i Danmark. Med megen ret hævder Poul Borum i sin bog "Digteren Grundtvig ", at "første bind af Sang-Værket (1837) må regnes som en af de betydeligste om ikke den betydeligste digtsamling på dansk «.

Blandt Vilh. Andersens elever var Paul V. Rubow nok den første til at bidrage til Grundtvig-forskningen. Som litterær personlighed var han sandt nok af den heibergske og den Georg Brandeske skole. I hvert fald var det næppe Vilh. Andersen, der havde vakt Rubows interesse for Grundtvig, snarere religionsforskeren $E d v$. Lehmann, der det meste af sit liv levede i exil i Berlin og senere i Lund, hvor han inspirerede en svensk forsker Sven Bergentz til at skrive en disputats om N.F.S. Grundtvigs religiøse idealisme (1923 - mere end 20 år før den første danske disputats om Grundtvig så lyset). Lehmann selv havde tidligere $\mathrm{i}$ en lille bog om Romantik og Kristendom lagt sig ud med de hjemlige grundtvigianere ved bl.a. at skrive "endnu den dag i dag lyder Schellings evangelium om den store enhed af ånd og natur igennem poesiens og religionens forklarelse fra grundtvigske lærestole uden at den, der taler, måske ved det mindste om, at det er Schelling, han forkynder."

Det var en påstand, som Lehmann fulgte op, da han som eme- 
ritus vendte tilbage til Danmark og skrev sin monografi Grundtvig (1929), der indeholder adskilligt nyt om Grundtvig som digter. Den blev kun i et tiår bogen om Grundtvig, da den for en tid afløstes af $\mathrm{Hal} \mathrm{Kochs,} \mathrm{der} \mathrm{bringer} \mathrm{meget} \mathrm{lidt} \mathrm{om} \mathrm{digteren.} \mathrm{Leh-}$ manns bog synes at være et varsel om en opdukkende renæssance for Grundtvigforskningen. Den øvede indflydelse på Rubow, der havde været lovlig kølig i sin dom over Grundtvigs krønikeoversættelser i guldmedaljeafhandlingen i bogen "Saga og Pastiche" 1919. I hans anmeldelse af Lehmanns bog fornemmes det klart, at han har fået et mere positivt syn på skribenten Grundtvig. Det kommer også til udtryk $\mathrm{i}$ hans fine lille motivundersøgelse "Himlens Nattergale» ("Gejstlige og verdslige Breve» 1937).

Grundtvig-forsker følte Rubow sig næppe kaldet til at blive. Men han fik interesse for Selskabets virke, selvom han erfaringsmæssigt havde sine tvivl om nytten af "disse selskaber for snart sagt ethvert af litteraturens store navne", der som regel har "en overvægt af ikke-litteratur-experte medlemmer", og som "taber sig i bisager".

Citaterne stammer fra hans anmeldelse af Grundtvig-Studier 1957 (Berlingske Aften 19/12 1957). Han anmeldte i GrundtvigSelskabets første årti regelmæssigt årbogen. Hvad han - trods sine principielle tvivl - håbede på, at Selskabet kunne bringe, fremgår formentlig af nogle linjer $i$ hans anmeldelse af årgangen 1955 (Berlingske Aften 9/12 1955), hvor det hedder: "Medens Søren Kierkegaard snart synes helt hjemfalden til Theologien og Kirken, er det en Trøst at se Grundtvig-Aarbogen domineret af tre litteraturhistoriske Doktere (sic!)«. Det er næppe for dristigt at opfatte disse provokerende ord som en tidlig påmindelse til Grundtvig-Selskabet om ikke at glemme digteren Grundtvig.

Allerede i begyndelsen af 1930'rne var der tegn på, at nogle unge litteraturforskere var på vej mod Grundtvig - f.ex. Emil Frederiksen, som i Gads danske Magasin offentliggjorde de kapitler om Grundtvig og Langeland, der senere indgik i hans bog "Den unge Grundtvig " (1946). Et par andre litterater, der havde overværet Vilh. Andersens inspirerende forelæsninger om Grundtvig (i slutningen af 1920erne): Magnus Stevns og undertegnede debuterede som Grundtvigforskere i det lille festskrift til deres lærer, der udkom til hans 60 års dag med titlen: „Fem danske Studier» (1934). 
Af de fem bidragydere skrev således to om digteren Grundtvig, en kendsgerning, som den tidligere Askov-lærer, dr. Marius Kristensen $\mathrm{i}$ en anmeldelse tog gode varsler af.

Jeg anfører dette for at pointere, at den genvakte interesse for Grundtvig og ikke mindst digteren Grundtvig ikke, som det så tit siges, var en følge af besættelsen 1940-45. Den var i udbrud fra begyndelsen af 30erne - og havde utvivlsomt forbindelse med både Vilh. Andersens og Lehmanns arbejder. Men det er evident, at studiet af Grundtvig fik vind i sejlene i de fem krigsår, og at denne vind også bar Grundtvig-Selskabet frem. Jeg skal ikke her gentage, hvad Høirup har fortalt om Selskabets stiftelse: blot understrege, at der med henblik på Selskabets videnskabelige virke fra starten blev sigtet mod et team work, hvor teologer-psykologerhistorikere, litteraturforskere og kort sagt alle tænkelige former for videnskabelighed kunne arbejde i fællig. Alle sider af Grundtvigs person og livsgerning skulle belyses.

Ved starten i Ribe bispegård var der jævnvægt mellem teologer og filologer (litteraturforskere), men man går vist ingen for nær ved at sige, at det særligt var humanister, litteraturforskere, der med Helge Toldberg som dynamisk inspirator lagde kræfterne i et fællesvirke med henblik på et dyberegående studium af Grundtvig.

Jeg skal ikke her søge at opremse alle de titler på bøger og afhandlinger, der blev resultatet af arbejdet i Grundtvig-Selskabets første decennier, og nøje afveje, hvem der i forskningen ydede mest - teologerne eller humanisterne. Men der er grund til særligt at pege på samvirkets første store frugt. Registranten af N. F. S. Grundtvigs papirer, de 30 bind, der udkom i årene 195664, og som i enestående grad er kommet Grundtvig-forskningen i vid forstand til gode. Her arbejdede teologer som Thaning, K. E. Bugge og Uffe Hansen i forbilledligt samarbejde med litteraturfolk som Steen Johansen, Niels Kofoed, William Michelsen, Helge Toldberg og undertegnede - under tilsyn af teologen Henning Høirup og filologen Peter Skautrup.

Men det var da nok specielt humanisterne, der var på jagt efter papirer, som kunne bidrage til belysningen af Grundtvigs profane - og det vil først og fremmest sige poetiske - forfatterskab. Det var også dem, der fandt det hensigtsmæssigt at henvende sig til Det danske Sprog- og Litteraturselskab for at få støtte - ikke blot 
økonomisk, men også administrativt til det store udgiverarbejde. Til al lykke kom et samarbejde i gang, og den store plan blev med bistand af Litteraturselskabets daværende administrator, dr. Albert Fabritius - effektueret.

Jeg skal ikke lægge skjul på, at jeg gerne så samarbejdet med Litteraturselskabet genoptaget i form af nye betydningsfulde udgaver. Det var mig i sin tid meget om at gøre at fa udgaven af Grundtvigs Dag- og Udtogsbøger fremmet gennem Litteraturselskabet, og jeg er glad for, at det lykkedes. Det var mit håb, at udgaven skulle være en slags begyndelse til en mere omfattende udgivelse af væsentlige, utrykte tekster fra Grundtvig-arkivet: i første række Grundtvigs breve. Steen Johansen og Flemming Lundgreen-Nielsen har gjort det forberedende arbejde - og planen har figureret på Litteraturselskabets liste over arbejder, der burde tages op - men er nu desværre på vej ud i glemselen.

Spørgsmålet er nu: Har vi forsømt noget, ikke været ivrige og dygtige nok til at forberede og organisere nye og store projekter til belysningen af digteren Grundtvig?

I vore dage er brugen af sponsorer kommet på mode. Jeg har med beundring set, hvorledes det er lykkedes Grundtvig-Selskabets initiativrige formand at rejse de fornødne midler til den store udgave af Grundtvigs pradikener; men jeg kan ikke nægte, at jeg ville have været endnu gladere, dersom vi samtidig kunne have fået brevudgaven i gang. Brevudgaven burde være en opgave, som i første række litteraturforskerne gik i gang med, men helt naturligt i samarbejde med Selskabets teologiske forskere.

Hvad med en kommenteret udgave af Grundtvigs digtsamlinger? Eller med en udgave af Grundtvigs dramatiske forfatterskab? Den store udgave af samlede skrifter făr formentlig ingen af os at se, men vi kunne godt begynde småt. Som jeg har nævnt ovenfor betragter jeg udgaven af Dag- og Udtogsbøgerne som en optakt til en sådan publikation. Flere bør følge efter. Jeg tør slet ikke tænke på så nærliggende - og så fjern - en opgave som en Grundtvig-Ordbog, et sidestykke til den store Holberg-Ordbog.

Med hvad jeg her har sagt, vil jeg gerne understrege, at jeg aldeles ikke vil sætte hegnspæle op og reservere digteren Grundtvig for litteraturens fagfolk. På lignende måde som nogle af litteraturforskerne - f.ex. dr. William Michelsen - med dygtighed, kyndighed og dybt personligt engagement har vovet sig ind på 
teologernes enemærker, må vi, der fagligt gerne skulle have vor force i studiet af digteren Grundtvig - og dermed forbundne filologiske emner - med glæde se bidrag om digteren Grundtvig skrevet af indsigtsfulde teologer som f.ex. Lise Helweg, hvis afhandling "Til Glæde for Graad " (om v-strukturen i Grundtvigs "håbssalmer ") udkom $\mathrm{i}$ den af Thodberg redigerede bog: "For Sammenhængens Skyld, ord og motiver i Grundtvigs salmer". Bogen, som ingen litterær fagmand kunne gøre bedre, tryktes forøvrigt i dobbeltårgangen 1977-78 af Grundtvig-Studier - så de fleste af Grundtvig-Selskabets medlemmer har formentlig læst den.

Når talen er, om Grundtvig-Selskabet har forsømt digteren Grundtvig kan jeg ikke lade være med at udtrykke min bekymring over, at Selskabet førte en mærkelig skyggetilværelse i det berømte jubelår 1983. I betragtning af den flod af tryksager, der strømmede frem i dagens anledning, kunne der måske nok være grund til at kritisere Selskabet for dets ringe aktivitet ved den lejlighed. Det blev Det danske Selskab, som præsenterede en stor Grundtvigbog ikke blot for danske, men for engelske, tyske og franske læsere (så mange eller så få de monne være). Titlen var på den danske udgave "Grundtvig og Grundtvigianismen i nyt lys. Hovedtanker og Udviklingslinjer. Fra de senere års Grundtvigforskning ". Titlen på de fremmedsproglige udgaver var: "N. F. S. Grundtvig. Tradition og Fornyelse. Grundtvigs Visioner vedrørende Mennesket, Folk, Opdragelse og Kirke og deres Betydning for Kirken ". Hvor er digteren henne i disse titler? Borte har taget ham.

I betragtning af, at bogens redaktører var mine gode århusianske kolleger, A.Pontoppidan Thyssen og Grundtvig-Selskabets formand - og langt de fleste bidragydere var medlemmer af Grundtvig-Selskabet, kunne man nok have ventet, at denne bog, der - mere eller mindre officielt - blev Grundtvig-Selskabets tribut til ære for den 200 årige, havde gjort noget mere ud af digteren Grundtvig. For han er selvsagt til stede i Flemming Lundgreen Nielsens kapitel om "Grundtvig and Romanticism ". Og naturligvis også i Chr. Thodbergs to bidrag: "Grundtvig the Hymn writer" og "Grundtvig the Preacher - the Poet in the Pulpit", hvor Thodberg lufter sin mageløse opdagelse, at man kan spore digteren $i$ en række af Grundtvigs prædikener. Allerede den gam- 
le pastor Hornsyld var inde på Thodbergs these, da han i slutningen af 1820erne læste en prædiken i Søndagsbogen og skrev til Grundtvig, at den kun manglede rytmen for at være en salme. Men den var ingen salme. Blev det måske.

Digteren Grundtvig er på færde i alt, hvad Grundtvig har med at gøre - og han spores i stort som småt. Dette være nævnt i beundring for Thodbergs ihærdighed. Jeg har ved tidligere lejligheder komplimenteret ham for det fine øre, han har over for poesien i Grundtvigs salmer og prædikentexter, omend jeg må mene, at han i sin iver finder for mange "digte" i Grundtvigs prædikener.

De øvrige bidrag i bogen rummer først og fremmest skildringer af Grundtvigianismen, højskolen og de grundtvigske kirketankers historie. Har jeg ret $i$ at betragte denne publikation fra Det danske Selskab - som Grundtvig-Selskabets skyldighed over for mindet om den Gamle - kan jeg ikke andet end at beklage, at man her i nogen måde har forpasset en oplagt lejlighed til at overbevise udlandet om, at en af Danmarks største digtere hedder N. F. S. Grundtvig.

Men skal der tales om forsømmelser, må der også tales om fortjenester. Jeg anser det for en stor fortjeneste, at det nu 40 årige selskab har været stærkt med til at udbrede kendskab til Grundtvigs virke og bidrage til en forskning, der omfatter den hele Grundtvig. Tiden har været med os, men jeg er overbevist om, at $v i$ også har bidraget til at skabe både interesse og respekt om Grundtvigs person og gerning - og ikke mindst skabt blivende interesse og høj vurdering af digteren Grundtvig - en så voldsom ændring i holdningen til ham, at det måske endog påny fører os over i defensiven. Grundtvig er nu accepteret, ja hyldet i kredse, der for et halvt århundrede siden stod ham imod. Det gælder måske specielt på litteraturens front. I den højere danske skole er Grundtvig nu en af de fă guldalderdigtere, som bliver doceret i dansk-timerne og af hvis digtning, der udgives særlige texthæfter.

Det er i denne forbindelse nok værd at minde om, at det var en mand uden for Grundtvig-Selskabet - en af tidens fineste lyrikere og skrappeste kritikere - Poul Borum - der til jubilæet 1983 skrev en bog om Digteren Grundtvig, og at han uden at ryste på sin hånd forfægtede den tese, at Grundtvig er Danmarks største digter.

$\mathrm{Nu}$ skal jeg ærlig bekende, at jeg har svært ved at finde ud af, 
hvordan man med sikkerhed kan fastslå en digters førsteplads - og forhold til andre store poeter. Men læsningen af Borums bog har styrket mig i min overbevisning om, at Grundtvig er en af vore store, ja meget store digtere.

Hvad der kan glæde en ved Borums - hastigt skrevne - men medrivende og i mange henseender overraskende bog - er ikke blot hans dybtgående - undertiden nok lidt hasarderede - analyser, men den optagethed og indfølingsevne, som præger fremstillingen. Han har fart på gennem hele værket og er ikke sen til at afvise forskere og forskningsresultater, som han finder henholdsvis dumme eller uunderbyggede, banale - eller fatale. Overalt i bogen nikker man til kendte navne, Høirup, Thodberg, Elbek, Michelsen, Stevns, Kofoed og Thaning, naturligvis. Og Lise Helweg. Og først og sidst et af de yngste led i kæden, litteraturforskeren, dr. Fl. Lundgreen Nielsen, som Borum gang på gang citerer med jublende tilslutning. Man kan ligefrem mærke, hvor Borum hopper i sædet i takt med slagene på skrivemaskinens taster. Så hyppigt må han give Lundgreen-Nielsen ordet, at han for at spare plads - og måske også for at holde tempoet - ikke anfører hans fulde navn, men forkorter det til FLN! En ære, som ikke overgår andre, men som er FLN velundt.

Så godt som alle navne på forskere med tilknytning til Grundtvig-Selskabet nævnes og citeres med nænsom kritik og storsindet hæder. Har Grundtvig-Selskabet ikke på anden måde mindet om sin eksistens og sine fortjenester ved 200 års-dagen - så er det sket her.

Det er værd at hæfte sig ved, at Borum ansporer til nye initiativer inden for udforskning af digteren Grundtvig. Han ægger en ny forskergeneration til at komme "udover arkivstadiet, hvor man finder alt, hvad Grundtvig har læst og gætter på, hvordan han er påvirket af det " - og i stedet f.ex. prøver "at se Grundtvig i parallel til den engelsk-amerikanske litteratur". Han anbefaler desuden "at afprøve Grundtvig på den radikalt nye romantikforskning “. Der er opgaver nok, både hvad textudgivelser og de videre forskningsinitiativer angår. Spørgsmålet er blot, om Grundtvig-Selskabet har kræfter og vilje til også i fremtiden at placere sig centralt i udforskningen af digteren Grundtvig. 